\title{
O polityczności Trybunału Konstytucyjnego w kontekście próby jego neutralizowania po wyborach 2015 roku
}

Streszczenie: Artykuł dotyczy zagadnienia polityczności w kontekście partyjności powoływania sędziów Trybunału Konstytucyjnego. Autor proponuje zastąpienie dotychczasowego paradygmatu tradycyjnego wskazującego na wybory/nominowanie przez Sejm, jako instytucję regulującą kreację. Przedstawia nowy paradygmat oparty na ateńskiej procedurze losowania, które umożliwiłoby powoływanie członków tego organu.

Słowa kluczowe: Trybunał Konstytucyjny, polityczność, partyjność, wybory, losowanie

\section{Uwagi wstępne}

Dolityczność można rozumieć jako władztwo w sferze publicznej, związane z narzucaniem własnej woli w obszarze makrostruktury. Jest to jedna z interpretacji polityczności. Polityka, może być wiązana z konfliktem występującym w sferze publicznej. Można ją także łączyć z procesem podejmowania decyzji, nakierowanym na uzyskiwanie rozstrzygnięcia w drodze konsensu. Wówczas polityczność oznacza poszukiwanie takich rozwiązań, które w obszarze strukturalnym i funkcjonalnym, prowadzą do podejmowania decyzji, które będą uwzględniać szerokie spektrum społeczne. W artykule stosuje się kategorię polityczność, która dotyczy szczególnego jej aspektu instytucjonalnego związanego z partyjnością. Polityczność i partyjność, to kategorie nietożsame. Jednak w dyskursie publicznym kategorie te są stosowane zamiennie. Nie należy ich utożsamiać w dyskursie naukowym. Partia polityczna, to szczególny przypadek organizacji politycznej, której celem jest zrealizowanie programu przez zdobycie i utrzymanie władzy publicznej. Partie polityczne są wyspecjalizowanymi instytucjami, które zajmują się reprezentowaniem interesów wielkich grup 
społecznych. Mają one różny charakter ideowy, programowy i organizacyjny. Partyjność jest sytuacją społeczną, która oznacza takie oddziaływanie partii politycznej na środowisko społeczne, które sprowadza się do bezpośredniego wpływania na proces społeczny/polityczny przez desygnowanie swoich członków i/lub zwolenników do pełnienia ważnych ról w procesie decydowania społecznego/politycznego.

W tytule artykułu umieszczone zostało słowo polityczność, chociaż rozważania w większym stopniu dotyczą zagadnienia partyjności. Nieustannie pojawiają się pytania o zakres kreowania organów państwa przez pryzmat partyjnego desygnowania osób do sprawowania funkcji. Nie budzą wątpliwości mechanizmy kreowania organów w obszarze władz ustawodawczych i wykonawczych w oparciu o kryterium partyjności. Kiedy jednak dotyczą one trzeciej władzy - w ramach powszechnie akceptowanej w modelach demokratycznych monteskiuszowskiej zasady trójpodziału władzy na ustawodawcza, wykonawczą i sądowniczą - występuje pogląd, że ta kreacja powinna być pozbawiona aspektu partyjnego. O ile, na poziomie aksjologicznym istnieje $\mathrm{w}$ tym zakresie konsens, to wymiar praktyczny stwarza konkretne wyzwania. Przyjmujemy, że deklaracje polityków są uczciwe i nie stanowią elementu prostej gry politycznej, która polega na budowaniu pozytywnego PR. Opinia publiczna akceptuje rolę partii politycznych w procesie artykulacji interesów grup społecznych, jednak nie w pełni akceptuje politykę podziału tupów, która kryterium partyjności wynosi ponad kompetencje nominatów. Ta jednak jest trudna do oceny na poziomie indywidualnym, kiedy składane są deklaracje o łączeniu zaangażowania partyjnego i kompetencji. W zasadzie zawsze głoszona jest teza, że osoba obejmująca funkcję posiada odpowiednie przygotowanie merytoryczne do pełnienia funkcji publicznej. Na rzecz tej tezy przytacza się argumenty empiryczne z działalności przeszłej lub przyjmuje logikę budowy modeli hipotetycznych, gdzie prawda łączona jest ze spełnieniem wymogu wewnętrznej spójności. Tak więc, opinia publiczna powiadamiana jest o decyzjach personalnych, które przedstawiane są jako wyraz połączenia właściwości merytorycznych i politycznych. Dopiero praktyka ukazuje opinii publicznej, jak jest naprawdę. W sytuacji większości parlamentarnej osiagniętej przez jedno ugrupowanie, poziom zaufania do partii rządzącej bezpośrednio po wyborach powszechnych, jest bardzo wysoki. To powoduje, że kreowanie organów państwowych w wymiarze personalnym, w oparciu o zasadę partyjności, posiada wysoki poziom akceptacji. Jest to bezpośrednią konsekwencją poparcia w wyborach. Zastanowienie przychodzi dopiero wówczas, gdy ugrupowanie 
rządzące nie spełnia obietnic wyborczych. Następuje wówczas urealnienie oceny i pojawiają się próby poszukiwania przyczyn niekorzystnych procesów społecznych. Jedną ze zmiennych jest aspekt personalny.

Monteskiuszowska zasada trójpodziału przyjmuje równowagę władz, a więc teoretycznie trzy władze powinny realizować przyznane im funkcje, nie wchodząc wzajemnie w swoje kompetencje. Jest to założenie wysoce teoretyczne, bo praktyka współczesnych państw demokratycznych, które przyjęły tę zasadę wskazuje, że trzy władze wzajemnie się przenikają. Wprawdzie ma to charakter ograniczony, jednak w modelowym rozwiązaniu amerykańskim zasada checks and balances nie w pełni jest realizowana.

Ważny aspekt stanowi kreowanie organów w wymiarze personalnym, szczególnie w odniesieniu do władzy sądowniczej. Przyjęte rozwiązania powodują, że władza ta kreowana jest przez władzę ustawodawczą lub/i wykonawczą. Innym rozwiązaniem jest kreowanie tych organów w wyborach powszechnych, jednak w tym ujęciu nie znosi to polityczności/ partyjności doboru. Nawet w większym stopniu upolitycznia/upartyjnia daną kandydaturę.

\section{Z tradycji sądownictwa konstytucyjnego w świecie}

Sądownictwo konstytucyjne, które oznacza sądową kontrolę prawa stanowionego z konstytucją, jest ważnym filarem współczesnego państwa prawnego. Wymaga to istnienia hierarchicznego systemu prawnego, gdzie konstytucja jest najwyższym aktem prawnym. Jest to związane $\mathrm{z}$ jej prawną nadrzędnością w stosunku do innych zjawisk prawnych i jej mocą prawną wynikającą z wyższej mocy prawnej prawa konstytucyjnego (Czeszejko-Sochacki, 1996, s. 11). Istotą tego typu działalności jest ochrona praw i wolności obywatelskich jednostki wyrażonych w konstytucji. Wprawdzie brak sądu konstytucyjnego nie oznacza, że kwestie te są pomijane w praktyce politycznej. Innym ważnym czynnikiem jest wysoki poziom kultury politycznej społeczeństwa, gdzie tworzenie prawa naruszającego literę konstytucji występuje w niewielkim zakresie. Możemy przyjąć, że tak się dzieje w demokracjach skonsolidowanych. Jest to jednak pogląd optymistyczny. Interesy polityczne poszczególnych grup, mogą prowadzić do wykorzystania chwilowej arytmetycznej większości parlamentarnej do naruszeń w tym obszarze. Praktyka światowa wskazuje, że mamy do czynienia z różnorodnością sądownictwa konstytucyjnego w zakresie strukturalnym i kompetencyjnym. 
Idea sądowej kontroli konstytucyjności narodziła się w XVII wieku w Anglii, która należy do państw nieposiadających konstytucji pisanej, w rozumieniu jednego aktu prawnego. W wymiarze praktycznym została wprowadzona do sfery publicznej w XVIII wieku w Stanach Zjednoczonych Ameryki Północnej. Wskazuje się na orzeczenie Sądu Najwyższego w sprawie Marbury v. Madison z 1803 roku, kiedy po raz pierwszy orzeczono o niekonstytucyjności aktu prawnego: „... logika całej konstytucji każe przyjąć teorię kontroli sądowej, bez której struktura państwa federalnego nie mogłaby się ostać" (Garlicki, 1987, s. 21-22).

Zasadniczo istnieją dwa podstawowe modele badania konstytucyjności prawa i model mieszany. W modelu amerykańskim, który ma charakter zdekoncentrowany, powierzono kontrolę konstytucyjności sądom powszechnym. W modelu europejskim kontrolą zajmuje się wyodrębniony organ sądowniczy - sąd konstytucyjny. W modelu mieszanym powołuje się odrębną izbę sądu najwyższego. Amerykańska koncepcja judicial review odnosi się nie tylko do zgodności ustaw z konstytucją, ale także do wszelkich aktów normatywnych, jak i działań urzędowych na wszystkich szczeblach władzy. Opiera się na założeniu, że każde naruszenie hierarchii norm prawnych czy działanie bez podstaw prawnych, jest naruszeniem konstytucji. Sądownictwo konstytucyjne w modelu europejskim powstało na gruncie austriackim i związane było z doktryną wiedeńskiej szkoły pozytywizmu prawniczego. Twórcą Trybunału Konstytucyjnego w Austrii był Hans Kelsen i to jego koncepcja znalazła swoją realizację w austriackiej konstytucji z 1920 roku. W okresie międzywojennym powstają w Europie tylko trzy trybunały: w Austrii i Czechosłowacji w 1920 roku oraz Hiszpanii w 1931 roku. Trybunały powstają w wielu państwach po II wojnie światowej: reaktywowany w Austrii w 1946 roku, we Włoszech w 1947 roku, Republice Federalnej Niemiec w 1949 roku, na Cyprze w 1960 roku, w Turcji w 1961 roku, w Jugosławii w 1963 roku, reaktywacja w Hiszpanii w 1978 roku, w Portugalii w 1982 roku, w Polsce w 1982 roku (w praktyce zaczyna działać w 1985 roku), na Węgrzech w 1989 roku, w Albanii, Bułgarii i Rumunii w 1991 roku, w Czechach, Słowacji i na Litwie w 1992 roku. Istnieją także wyspecjalizowane organy ochrony konstytucji w innych państwach, jednak ich zakres działania jest bardzo okrojony. Modele mieszane powstawały głównie w Ameryce Łacińskiej.

W istocie rozwiązania strukturalne mają znaczenie wtórne. Tak wiec, przyjęcie jednego z modeli jest sprawą związaną ze specyfiką danego państwa. Bardziej istotny jest aspekt funkcjonalny, a więc jakie są prak- 
tyczne możliwości realizowania funkcji ochrony praw i wolności obywatelskich jednostki w społeczeństwie. Niebezpieczną jest sytuacja, kiedy arytmetyczna większość parlamentarna, sprawująca władzę przez jedną lub dwie kadencje, wprowadzałaby rozstrzygnięcia w tym zakresie, które naruszałyby konstytucyjne prawa i wolności obywatelskie. Idea powstrzymywania władzy chwilowej arytmetycznej większości jest zgodna z ideą demokracji liberalnej (Gutman, 1998, s. 533-535). Ideę przeciwstawną znajdziemy w koncepcji demokracji schumpeterowskiej i populistycznej, gdzie rządząca większość parlamentarna ma wyłączny mandat na kreowanie prawa, nawet kiedy tworzy prawo kontrowersyjne z punktu widzenia legalistycznego. To w takiej sytuacji, istotną rolę odgrywa sądownictwo konstytucyjne.

\section{Pozycja ustrojowa Trybunału Konstytucyjnego w Polsce}

Idea powołania sądu konstytucyjnego pojawiła się w Polsce w okresie międzywojennym, kiedy prowadzono prace nad konstytucjami Marcowa z 17 marca 1921 roku i Kwietniowa z 23 kwietnia 1935 roku. Ostatecznie zrezygnowano $\mathrm{z}$ ustanowienia tego organu. Ideę tę urzeczywistniono dopiero w 1982 roku. W powojennej Polsce Ludowej w latach czterdziestych i pięćdziesiątych nie przewidziano jakichkolwiek form kontroli konstytucyjności ustaw. Uważano, że kolidowałoby to z doktryną ustrojową, gdzie parlament - jako emanacja suwerena - sam zajmował się badaniem konstytucyjności. Dopiero w latach sześćdziesiątych i siedemdziesiątych pojawiają się idee kontroli konstytucyjności. Nowela konstytucyjna z 10 lutego 1976 roku nadała Radzie Państwa kompetencje czuwania nad zgodnością prawa z Konstytucją. Powstanie Solidarności w 1980 roku przyśpieszyło materializowanie się idei sądownictwa konstytucyjnego w Polsce. Paradoksem jest to, że kreowanie tego organu w wymiarze formalnym zaczyna się w okresie stanu wojennego. W praktyce Trybunał Konstytucyjny zaczyna działalność w 1985 roku.

Powstanie Trybunału Konstytucyjnego w Polsce zostało przyjęte negatywnie przez rządzących, w niektórych państwach realnego socjalizmu. Organ ten był postrzegany, jako zagrożenie dla socjalizmu. Akademia Nauk Niemieckiej Republiki Demokratycznej wyraziła bardzo krytyczną opinię w stosunku do utworzenia w Polsce Trybunału Konstytucyjnego i Trybunału Stanu, twierdząc, że wywoła to „niebezpieczeństwa polityczne dla ustroju socjalistycznego”, z uwagi na „wmontowanie do 
politycznej struktury socjalizmu elementów burżuazyjnego prawa państwowego", jednoznacznie wskazując, że działalność Trybunału nie może stanowić „udoskonalenia, lecz w określonej mierze stanowi deformację socjalizmu" (Granat, 2003, s. 94).

Działający w tym okresie Trybunał Konstytucyjny nie miał prawa ostatecznego rozstrzygania zagadnienia konstytucyjności aktów ustawodawczych, gdyż Sejm mógł je oddalić kwalifikowaną większością 2/3. Natomiast w stosunku do aktów prawnych niższej rangi moc pozostawała wiążąca. Istotne przemiany rozpoczęły się wraz z przyjęciem ustaleń Okrągłego Stołu w 1989 roku. Przeprowadzono dwie nowelizacje Konstytucji z 7 kwietnia i 29 grudnia 1989 roku, które wprowadziły ważne zmiany ustrojowe, także w odniesieniu do tego organu. Istotną sprawą było wprowadzenie do Konstytucji zasady demokratycznego państwa prawnego. Uchwalenie Małej Konstytucji 17 października 1992 roku nadawało nową rangę podziałowi władz, który opierał się na zasadzie równorzędności i jednocześnie odrzucono obowiązującą zasadę jedności władz. Istotnym z punktu widzenia pozycji Trybunału Konstytucyjnego było przyjęcie przez Trybunał orzeczenia, że jeżeli Sejm w ciągu sześciu miesięcy nie rozpatrzy orzeczenia dotyczącego niekonstytucyjności ustawy, to orzeczenie Trybunału zachowuje moc obowiązującą i uchyla ustawę (Uchwała Trybunału Konstytucyjnego z 20 października 1993 r.). Nie dawało to powszechnie obowiązującej ostateczności, lecz było jej namiastką. Sejm mógł odrzucić orzeczenie kwalifikowaną większością głosów, jedynie w ciągu sześciu miesięcy od dnia przedstawienia orzeczenia. Uchwalenie Konstytucji w dniu 2 kwietnia 1997 roku otwiera nowy rozdział w działalności Trybunału Konstytucyjnego. Materię dotyczącą Trybunału Konstytucyjnego rozmieszczono w paragrafach 188-197 (Konstytucja Rzeczypospolitej Polskiej z dnia 2 kwietnia 1997 r.). Wprowadziła ona korzystne zmiany z punktu widzenia pozycji, właściwości i organizacji Trybunału Konstytucyjnego pośród organów państwowych. Rozpoczęła się zmiana modelu konstytucyjności prawa. Zgodnie z Konstytucją w dniu 1 sierpnia 1997 roku przyjęto nową ustawę o Trybunale Konstytucyjnym. Rozszerzono kompetencje i właściwości: 1. Trybunał zaliczono do władzy sądowniczej; 2. Rozszerzono funkcje kontroli pod względem materialnym i formalnym, poszerzając o umowy międzynarodowe i nową instytucję skargi konstytucyjnej; 3. Dodano rozstrzyganie sporów kompetencyjnych pomiędzy centralnymi konstytucyjnymi organami państwa; 4. Orzeczeniom Trybunału nadano moc powszechnie obowiązującą i ostateczną, z nadaniem uprawnienia określania terminu utraty 
mocy obowiązującej aktu normatywnego; 5. W indywidualnych sprawach rozstrzyganych przez sąd lub organ władzy publicznej Trybunał określa retroaktywność orzeczeń niezgodnych z konstytucją; 6. Zwiększono skład Trybunału Konstytucyjnego do piętnastu sędziów i wydłużono kadencję do dziewięciu lat.

Trybunał Konstytucyjny posiada kompetencje ustalania norm konstytucyjnych i określania ich skutków prawnych w sposób ostateczny oraz wiążący wszystkie pozostałe organy państwowe (Czeszejko-Sochacki, 2003, s. 95-97).

\section{Ksztalt personalny Trybunału Konstytucyjnego w kontekście jego polityczności}

Zgodnie z art. 194 ust. 1 Konstytucji z 1997 roku: „,Trybunał Konstytucyjny składa się z 15 sędziów, wybieranych indywidualnie przez Sejm na 9 lat spośród osób wyróżniających się wiedzą prawniczą. Ponowny wybór do składu Trybunału jest niedopuszczalny". Wybór dokonywany jest bezwzględną większością głosów na wniosek pięćdziesięciu posłów lub Prezydium Sejmu. Art. 194 ust. 2 rozstrzyga, że: „Prezesa i Wiceprezesa Trybunału Konstytucyjnego powołuje Prezydent Rzeczypospolitej spośród kandydatów przedstawionych przez Zgromadzenie Ogólne Sędziów Trybunału Konstytucyjnego".

Na stanowisko sędziego Trybunału może ubiegać się osoba wyróżniająca się wiedzą prawniczą. Zgodnie z art. 195 Konstytucji, ustawa doprecyzowała, że są to osoby posiadające kwalifikacje wymagane do zajmowania stanowiska sędziego Sądu Najwyższego lub Naczelnego Sądu Administracyjnego.

Przyjęcie założenia, że sędziowie są wybierani przez Sejm - a więc ciało polityczne - wskazuje na polityczny charakter tego aktu. Naturalnym więc jest podejmowanie prób przez większość parlamentarną, ażeby funkcje te pełnione były przez osoby spełniające kryteria merytoryczne, jednak reprezentujące poglądy ideowe i polityczne bliskie tej większości. Nie oznacza to, że osoba wybrana przez określoną grupę polityczna, będzie bezrefleksyjnie działać w jej politycznym interesie. Konstytucja w art. 195 ust. 3 jednoznacznie określa, że: „Sędziowie Trybunału Konstytucyjnego w okresie zajmowania stanowiska nie mogą należeć do partii politycznej, związku zawodowego ani prowadzić działalności publicznej nie dającej się pogodzić z zasadami niezależności sądów i niezawisłości 
sędziów". Z formalnego punktu widzenia zabezpieczona została apolityczność sędziów, którzy w okresie sprawowania funkcji w Trybunale Konstytucyjnym nie mogą podejmować działan, które nie byłyby do pogodzenia z zasadą niezależności sądów i niezawisłości sędziów. Jednak fakt desygnowania na stanowisko sędziego Trybunału Konstytucyjnego skłania do zastanowienia się czy w rzeczywistości możliwa jest pełna niezależność. Praktyka wskazuje, że sędziowie zachowują dystans do polityki. Istotną rolę odgrywa kultura etyczna, która nakazuje działania zgodne z prawem i nieuleganie naciskom politycznym. Naciski polityczne moga mieć charakter zewnętrzny, ale także stanowić rezultat presji przekonań politycznych, które reprezentują sędziowie. To drugie uwarunkowanie odgrywa ważne znaczenie, gdy weźmiemy pod uwagę system wartości ideologicznych i światopoglądowych. Każdy człowiek - także sędzia - ma zinternalizowany system aksjologiczny, który wyznacza widzenie świata $i$ jego ewaluację. Jest to istotny czynnik oceniania świata i podejmowania konkretnych rozstrzygnięć. To immanentna cecha każdej jednostki, nawet kiedy nie uświadamia sobie tego faktu. W tej sytuacji wybór sędziego dodatkowo obarczony jest poszukiwaniem osoby, która spełnia oczekiwania w tym zakresie. Po wyborze nowych sędziów Trybunału Konstytucyjnego przez większość parlamentarną ukształtowaną po wyborach 2015 roku, uwagę zwraca podobna ocena dwóch nowo wybranych sędziów, w odniesieniu do ustawy dotyczącej Trybunału Konstytucyjnego. Sędziowie Julia Przyłębska (zdanie odrębne) i Piotr Pszczółkowski (votum separatum), nie podzielali zgodnej oceny pozostałych członków Trybunału Konstytucyjnego uczestniczących w rozprawie (Nowelizacja ustawy o Trybunale Konstytucyjnym, sygn. akt K 47/15, Wyrok w imieniu Rzeczypospolitej Polskiej, Warszawa, dnia 9 marca 2016 r.). Wraz $\mathrm{z}$ większym stażem w Trybunale Konstytucyjnym, afiliacje polityczne odgrywają mniejsze znaczenie w orzekaniu.

Konstytucja wprowadziła zabezpieczenia, które umożliwiają sędziom takie funkcjonowanie, które nie naraża ich na działania innych władz państwowych. Hipotetycznie władze te mogłyby zmierzać do uzależnienia Trybunału Konstytucyjnego. Artykuł 196 stwierdza: „Sędzia Trybunału Konstytucyjnego nie może być, bez uprzedniej zgody Trybunału Konstytucyjnego, pociagnięty do odpowiedzialności karnej ani pozbawiony wolności. Sędzia nie może być zatrzymany lub aresztowany, z wyjątkiem ujęcia go na gorącym uczynku przestępstwa, jeżeli jego zatrzymanie jest niezbędne do zapewnienia prawidłowego toku postępowania. O zatrzymaniu niezwłocznie powiadamia się Prezesa Trybunału Konstytucyj- 
nego, który może nakazać natychmiastowe zwolnienie zatrzymanego". Takie zabezpieczenia są konieczne - chociaż czasami są krytykowane - ze względu na mogące wystąpić nadużycia, to jednak bez tej regulacji istniałoby realne zagrożenie oddziaływania innych władz na Trybunał Konstytucyjny. Wspomniane uprzednio wymogi stawiane członkom tej instytucji, stanowią rękojmię, że osoby te powinny reprezentować najwyższe standardy moralne. W wymiarze praktycznym, mogłyby się pojawić sytuacje, które świadczyłyby o niespełnianiu tych warunków. Twórcy konstytucji wskazali prezesa Trybunału, który rozstrzyga czy ewentualne zarzuty wobec sędziego Trybunału Konstytucyjnego są tak poważne, że należy utrzymać w mocy zatrzymanie. Konstytucja nie przewiduje, co należy zrobić, gdyby w takiej sytuacji znalazł się prezes.

\section{Kwadratura koła i perspektywa jej likwidacji}

Czym jest wymieniona w podtytule artykułu kwadratura koła? Chodzi tutaj o sprzeczność pomiędzy postulatem apolityczności/apartyjności a wyborem członków Trybunału Konstytucyjnego przez niższą izbę parlamentu Sejm, która jest ciałem politycznym. Jak już wspomniano, uprawnienia Sejmu w zakresie kreowania organów wykonawczych są z natury swej polityczne, o tyle wybór członków władz sądowniczych nasuwa wątpliwości dotyczące niezależności organu i niezawisłości jego członków. Spory dotyczące kreacji personalnej Trybunału Konstytucyjnego, jakie wystapiły na forum polskiego Sejmu po wyborach z 25 października 2015 roku, wskazują jednoznacznie na wymiar polityczny/ partyjny. Chęć desygnowania swoich przedstawicieli w tym organie pokazały dwie znaczące siły polityczne w Polsce: Platforma Obywatelska oraz Prawo i Sprawiedliwość.

Artykuł 17 ustawy z dnia 25 czerwca 2015 roku stanowi: „1. W skład Trybunału wchodzi piętnastu sędziów. 2. Sędziów Trybunału wybiera indywidualnie, na dziewięcioletnie kadencje, Sejm bezwzględną większością głosów, w obecności co najmniej połowy ustawowej liczby posłów. Ponowny wybór do Trybunału jest niedopuszczalny". W art. 19 przyjęto, że: 1. Prawo zgłaszania kandydata na sędziego Trybunału przysługuje Prezydium Sejmu oraz grupie co najmniej 50 posłów. 2. Wniosek w sprawie zgłoszenia kandydata na sędziego Trybunału składa się do Marszałka Sejmu nie później niż 3 miesiące przed dniem upływu kadencji sędziego Trybunału." (Ustawa z dnia 25 czerwca 2015 r. o Trybunale Konstytucyjnym). 
Po wyborach parlamentarnych 2015 roku i objęciu rządów przez Prawo i Sprawiedliwość - w koalicji z ugrupowaniami Polska Razem i Solidarna Polska - uchwalono nowelizacje ustawy dotyczącej Trybunału Konstytucyjnego (Ustawa z dnia 22 grudnia 2015 r. o zmianie ustawy o Trybunale Konstytucyjnym). Została ona zaskarżona do Trybunału Konstytucyjnego i w dużej części orzeczona została niezgodność z Konstytucją (Nowelizacja ustawy o Trybunale Konstytucyjnym, Sygn. akt K 47/15, Wyrok w imieniu Rzeczypospolitej Polskiej, Warszawa, dnia 9 marca $2016 r$.). Zmiany te dotyczyły przede wszystkim procedowania Trybunału Konstytucyjnego. Sprawy wyboru członków tego organu nie stanowiły jej istoty. Problem nie został więc rozwiązany i będzie wracał na wokandę polityki.

Politycy reprezentują podejście do tego zagadnienia w ramach tradycyjnego paradygmatu, gdzie kreacja personalna organów państwowych i samorządowych powinna dokonywać się w ramach wyborów lub desygnowania osób do pełnienia funkcji publicznych. Uzasadnienie znajduja w doktrynie suwerenności narodu/ludu. Odwołują się do wspomnianych już tradycyjnych koncepcji demokracji, gdzie wola wyborców traktowana jest jako mandat do decydowania politycznego. Jest to interpretacja uproszczona, ale trudno odmówić jej logiki. Skoro wynik wyborów wskazał większość rządzącą, to należy uznawać wolę suwerena. Jednak należałoby wprowadzić pewne zastrzeżenie, które dotyczy adekwatności zmian w przestrzeni publicznej do stopnia uzyskanego poparcia. W praktyce w wyborach centralnych bierze udział 40-60\% osób uprawnionych do głosowania. W tej sytuacji mandat do rządzenia jest legalny, ale z merytorycznego punktu widzenia niepetny. Formalnie ugrupowanie/ugrupowania, które zdobywa większość arytmetyczną ma mandat do podejmowania decyzji. Jednak głębokość decydowania powinna mieć związek z frekwencja, co daje wiedzę na temat rzeczywistego poparcia społecznego. W wyborach parlamentarnych 2015 roku w Polsce było 30629150 osób uprawnionych do wzięcia udziału w głosowaniu. Frekwencja wyborcza wyniosła 15597073 osób tj. 50,92\%. Na ugrupowanie zwycięskie oddano 5711687 głosów. To jest wskaźnik rzeczywistego poparcia dla ugrupowania politycznego, które uzyskało bezwzględną liczbę mandatów w Sejmie (Obwieszczenie Państwowej Komisji Wyborczej z dnia 27 października 2015 r. o wynikach wyborów do Sejmu Rzeczypospolitej Polskiej przeprowadzonych w dniu 25 października 2015 r.). Zadowalający, ale nie w pełni satysfakcjonujący poziom uczestnictwa stawia pytanie o zakres możliwych ingerencji w ustrój polityczny państwa. Sprawa nie 
nasuwa wątpliwości z formalnego punktu widzenia, jednak zastrzeżenia pojawiają się $\mathrm{w}$ aspekcie merytorycznym. Ponadto ważną sprawą jest - w przypadku wyborów powszechnych organizowanych w trybie proporcjonalnym - jaka zostanie zastosowana metoda przełożenia głosów na mandaty: popularna metoda Victora d'Hondta (dająca dodatkowe mandaty ugrupowaniu, które uzyskało większe poparcie) czy np. Sainte-Laguë (dająca dodatkowe mandaty ugrupowaniu, które uzyskało mniejsze poparcie). Wybór metody przeliczeniowej bywa przedmiotem gry przedwyborczej.

W tej sytuacji zasadne jest postawienie pytania: czy desygnowanie/ wybór przez Sejm sędziów Trybunału Konstytucyjnego, którego podstawowym zadaniem jest badanie konstytucyjności aktów prawnych, jest najlepszym sposobem? Tak postawione pytanie wymaga jednoznacznej odpowiedzi: nie! Alternatywą jest przyjęcie rewolucyjnego paradygmatu, który odwołuje się do praktyki politycznej demokracji ateńskiej okresu antyku, kiedy w VI i V w. p.n.e. wprowadzono instytucję losowania. Kreowanie organów dokonywało się z wykorzystaniem przypadku, który był praktyczną realizacją isonomii, a więc równości praw. W Atenach wytworzyła się specyficzna forma ustrojowa, którą określamy jako demokrację, jednak w praktyce była to odmiana szczególnej oligarchii, gdzie wyraźnie oznaczona grupa osób uczestniczyła w sprawach publicznych. Byli to dojrzali mężczyźni o udokumentowanym pochodzeniu ateńskim. Pozostałe grupy mieszkańców Aten nie korzystały z uprawnienia uczestniczenia w życiu publicznym. Jednak wypracowane wówczas instytucje polityczne weszły do kanonu instytucji demokratycznych. W sensie technologicznym, z pewnością możemy je traktować jako demokratyczne. Jednak biorąc pod uwagę współczesne rozumienie demokracji, to demokracja ateńska miała wymiar ograniczony do instytucji technicznych.

$\mathrm{Z}$ pewnością demokratyczne rozwiązania antyczne w zakresie losowania wykorzystywane w Atenach, mogłyby zostać włączone do zbioru współczesnych instrumentów demokratycznych. Dominuje jednak przekonanie, że miarą skutecznej polityki jest prowadzenie określonej polityki personalnej, która opiera się na osobach darzonych zaufaniem na płaszczyźnie poza merytorycznej. Tak więc politycy, którzy uczestniczą w procesie personalnego kreowania organów (przy tym korzystają z tego uprawnienia $\mathrm{w}$ aspekcie czynnym i biernym) nie są zainteresowani upowszechnieniem tej procedury. Najczęściej wskazują oni na aspekt merytoryczny, powołując się na konkursy, jako narzędzia doboru najlepszego kandydata. 
Współcześnie stosuje się losowanie, jako sposób kreowania organu/ instytucji w wymiarze personalnym. Najbardziej znanym jest powoływanie ławy przysięgtych $\mathrm{w}$ amerykańskim systemie sądowniczym. Nic więc nie stoi na przeszkodzie, ażeby zdecydować się na przyjęcie paradygmatu - który podkreślając zasadę powszechności - daje możliwość powoływania sędziów Trybunału Konstytucyjnego w drodze losowania. Nie wdając się w szczegóły, można stworzyć prostą procedurę desygnowania przez określone gremia (one także mogą pochodzić z losowania i każdorazowo może to być inna instytucja przedstawiająca kandydatury) kandydatów na sędziów np.: Krajowa Rada Sądownictwa, Sąd Najwyższy, Naczelny Sąd Administracyjny, senaty uniwersytetów itp. Kandydaci, którzy spełnią określone wymogi merytoryczne (można to określić na poziomie sprecyzowanych certyfikatów ukończenia kształcenia i/lub praktyki) przechodzą swoistą dokimazję, a następnie wprowadzani są na listę kandydatów. $\mathrm{Z}$ tej grupy kandydatów przeprowadza się losowanie. Można taką grupę bardziej zróżnicować, losując sędziów w ramach reprezentatywnych i proporcjonalnych podgrup, które budowane byłyby przez ściśle określone gremia. Jest to rozwiązanie proste i dające gwarancję apartyjności. Czy eliminuje to zastrzeżenia związane z osobistymi przekonaniami jednostek? Z pewnością nie. Sędziowie będą mieli swoje przekonania, jednak nie będą ich uwidaczniać - ażeby spodobać się politykom - jako kandydaci do tego ciała. Dawałoby to nawet możliwość rezygnacji z kadencyjności, bo przestałoby istnieć niebezpieczeństwo powstawania klientyzmu - kadencje więc mogłyby być krótsze. Losowanie można upowszechnić na inne obszary kreowania organów i instytucji w przestrzeni publicznej (Zyborowicz, 2013, s. 47-49). Stanowi to wyzwanie dla politologów w zakresie konstruowania szczegółowych modeli normatywnych, które wykorzystywałyby lottodemokrację. Możliwe są proste modele homogeniczne, ale także heterogeniczne. W przypadku pierwszych losowanie byłoby jedyną techniką kreowania organu, zaś w przypadku drugich stanowiłoby ich część i w połączeniu z wyborami, stworzyłoby kompatybilną całość.

\section{Uwagi końcowe}

Trybunał Konstytucyjny stanowi ważny organ w systemie państwa prawnego w Polsce. Jako jeden z filarów trójpodziału władzy opartego na ich równości stwarza warunki decydowania politycznego, które oparte 
jest na zasadzie poszanowania praw i wolności obywatelskich. Zajmując się badaniem zgodności aktów prawnych z konstytucją, daje podstawy państwa prawnego.

Sposób personalnego kreowania tego organu dokonuje się w ramach dominującego paradygmatu politycznego. Współczesna praktyka wymaga jednak nowego spojrzenia, które może sprzyjać redukcji polityczności/ partyjności, które mogą pojawić się w wymiarze praktycznym jego działania. Doświadczenia ostatnich kilkunastu miesięcy wskazują na traktowanie tego organu, jako potencjalnego łupu politycznego. Wprowadzenie instytucji losowania mogłoby się przyczynić do wykreowania nowej jakości budowania personalnego organów i instytucji życia publicznego.

Idea powszechności może urzeczywistniać się za pomocą techniki losowej, która przez fakt przypadkowego wyboru, daje szansę, że powołany w ten sposób organ będzie emanacją społeczeństwa ze swoimi zaletami i wadami. Skutecznie wyeliminuje duży odsetek osób, które posiadając zdolności demagogiczne, zdobywają poparcie wyborców z powodu swoich umiejętności przekonywania do siebie. Wprawdzie nie jest to nadmiernie naganne, jednak uczestnictwo w polityce publicznej, a więc nade wszystko w procesie decydowania politycznego, wymaga w wiele większym zakresie kompetencji merytorycznych. Przekonywanie do siebie nie jest najważniejszą cechą, którą powinien posiadać polityk. Chociaż te umiejętności też odgrywają rolę w procesie kreowania decyzji.

Dotychczasowe doświadczenia praktykowania demokracji loteryj$n e j$, napawają optymizmem. Wymagana jest jednak odwaga i rezygnacja $\mathrm{z}$ partyjnych partykularyzmów w interesie publicznym - actum est de republica. Takim dobrem może być apolitycznie/apartyjnie wykreowany Trybunał Konstytucyjny.

\section{Bibliografia}

Czeszejko-Sochacki Z. (1996), Są konstytucyjny w systemie organów państwowych. Studia i materiaty, Wydawnictwa Trybunału Konstytucyjnego, Warszawa.

Czeszejko-Sochacki Z. (2003), Sadownictwo konstytucyjne w Polsce na tle porównawczym, Wydawnictwa Trybunału Konstytucyjnego, Warszawa.

Granat M. (2003), Sadowa kontrola konstytucyjności prawa w państwach Europy Środkowej $i$ Wschodniej. Na tle niektórych zasad ustrojowych, Wydawnictwo Sejmowe, Warszawa.

Gutman A. (1998), Demokracja, w: Przewodnik po wspótczesnej filozofii politycznej, red. R. E. Goodin, P. Pettit, Książka i Wiedza, Warszawa. 
Konstytucja Rzeczypospolitej Polskiej z dnia 2 kwietnia 1997 r. uchwalona przez Zgromadzenie Narodowe w dniu 2 kwietnia 1997 r., przyjęta przez Naród w referendum konstytucyjnym w dniu 25 maja 1997 r., podpisana przez Prezydenta Rzeczypospolitej Polskiej w dniu 16 lipca 1997 r., Dz. U. 1997, Nr 78, poz. 483.

Nowelizacja ustawy o Trybunale Konstytucyjnym, Sygn. akt K 47/15, Wyrok wimieniu Rzeczypospolitej Polskiej, Warszawa, dnia 9 marca 2016 r., http://trybunal. gov.pl/rozprawy-i-ogloszenia-orzeczen/wyroki-i-postanowienia/art/8859-nowelizacja-ustawy-o-trybunale-konstytucyjnym/.

Obwieszczenie Państwowej Komisji Wyborczej z dnia 27 października 2015 r. o wynikach wyborów do Sejmu Rzeczypospolitej Polskiej przeprowadzonych w dniu 25 października 2015 r., http://parlament2015.pkw.gov.pl/pliki/1445959303_ obwieszczenie_sejm_wybory_wyniki.pdf.

Uchwała Trybunału Konstytucyjnego z dnia 20 października 1993 roku w sprawie wykładni art. 7 ust. 2 ustawy z dnia 29 kwietnia o Trybunale Konstytucyjnym, Dz. U. 1993, Nr 105, poz. 481.

Ustawa z dnia 25 czerwca 2015 r. o Trybunale Konstytucyjnym, Dz. U. 2015, poz. 1064.

Ustawa z dnia 22 grudnia 2015 r. o zmianie ustawy o Trybunale Konstytucyjnym, Dz. U. 2015, poz. 2217.

Zyborowicz S. (2013), Democracy by lottery: implication for practice, „The Polish Political Science Quarterly", no. 1, ss. 41-50.

\section{About the politicization of the Constitutional Tribunal in the context of attempts to neutralize it after the 2015 elections}

\section{Summary}

The paper examines the issue of politicization given the context of party affiliation of judges appointed as members of the Constitutional Tribunal. The author suggests that the present traditional paradigm of appointment/selection by the Parliament as a regulatory institution is replaced and presents a new paradigm based on choosing lots as employed in ancient Athens to appoint members of the Constitutional Tribunal.

Key words: Constitutional Tribunal; politicization, partisanship, elections, draw 